\title{
The Impact of Natural Disasters, Technological Change and Education on Poverty Rate: Evidence from Developing Countries
}

\author{
(Kesan Bencana Alam, Perubahan Teknologi dan Pendidikan ke atas Kadar Kemiskinan: Bukti dari \\ Negara-Negara Membangun)
}

Jaharudin Padli

Universiti Malaysia Terengganu

Nizam Ahmat

Universiti Malaysia Terengganu

Mohd Nasir Nawawi

Universiti Malaysia Terengganu

\begin{abstract}
This study aims to analyze the impacts of natural disasters (total affected and total damages), technological change and education on poverty rates using 38 selected developing countries over the period of 1984-2013. A panel regression method is used in estimating the model. The results show that more impactful natural calamities will increase the poverty rate (positive relationships), while the impact of technological change has brought the poverty rate down to the lowest level (negative relationships). However, this study finds positive relationships between technological change and poverty, with an increase in technology causing a rise in poverty. The study also reveals a negative relationship between education on poverty. This implies that improvements in education can play an important role in increasing welfare and reducing poverty in developing countries. The results of this study suggest that education might be the best solution for minimizing the impact of natural disaster and poverty avoidance.
\end{abstract}

Keywords: Natural disaster; poverty rate; technological change

\section{ABSTRAK}

Kajian ini bertujuan untuk menganalisis kesan bencana alam (jumlah mangsa yang terjejas dan jumlah kerugian), perubahan teknologi dan pendidikan ke atas kadar kemiskinan dengan menggunakan data 38 buah negara membangun yang terpilih dari tahun 1984-2013. Kaedah regresi data panel telah digunakan untuk penganggaran model. Keputusan penganggaran menunjukkan bahawa kesan peningkatan bencana alam telah meningkatkan kadar kemiskinan ke tahap yang lebih tinggi (hubungan positif). Sementara itu, kesan perubahan teknologi telah mengurangkan kadar kemiskinan ke tahap yang paling rendah (hubungan negatif). Walau bagaimanapun, kajian ini mendapati hubungan yang positif antara perubahan teknologi dengan kadar kemiskinan. Ini bermakna peningkatan dalam teknologi telah menyebabkan kenaikan dalam kadar kemiskinan di negara-negara membangun. Kajian juga mendapati bahawa impak pendidikan ke atas kadar kemiskinan adalah berhubungan secara negatif. Ini menunjukkan bahawa peningkatan pendidikan mempunyai peranan penting dalam meningkatkan kebajikan dan mengurangkan kemiskinan di negara-negara membangun. Dapatan kajian ini menunjukkan bahawa pendidikan mungkin boleh menjadi penyelesaian terbaik untuk meminimumkan kesan bencana alam dan mengelakkan kemiskinan.

Kata Kunci: Bencana alam; kadar kemiskinan; perubahan teknologi

\section{INTRODUCTION}

Natural disasters such as floods, earthquakes, typhoons, droughts and volcanic eruptions have an enormous impact around the world, causing death, injury and destruction to property. For example, reports by the World Health Organization (2016) have shown that natural disasters instigate global losses of US\$520 billion, with 26 million people living in poverty in 2015 . More than $70 \%$ of low-income groups are in countries at high risk of natural catastrophes. Therefore, according to an economic perspective, a natural disaster can be defined as an event that causes disruption to the function of the economic system, with a marked negative impact on assets, production factors, outputs, employment and consumption (Hallegatte \& Prsyluski 2010). Thus, to determine households' sensitivity and vulnerability to hazards from natural disasters, the level of income is an important factor capturing people's conditions of poverty, because poverty exacerbates the negative impacts on the household in terms of increasing the severity of existing poverty. Three studies have discussed 
the influence of disasters on poverty and consumption through the destruction of assets (Berloffa \& Modena 2013; Jakobsen 2012; Mechler 2009).

Thus, a natural disaster is closely linked to poverty. The World Bank (1990) has discovered that more than $80 \%$ of the supposed poor are not "always poor" but rather "sometimes poor", because it is difficult for them to resist various natural disasters and so they fall into poverty or return to a poverty situation. The occurrence of natural disasters has a tremendous negative effect, especially in the agricultural sector. The effect of natural disasters in undeveloped areas is particularly serious and can lead to the widespread occurrence of poverty due to a weak capacity to handle such disasters (Qianwen \& Junbiao 2007). Therefore, the significant damage wrought by natural disasters greatly affects these countries (for example in Ethiopia and Honduras) and stimulates a rise in poverty gaps (Carter et al. 2007). Developing countries lack the necessary budget to manage damage effectively. Consequently, the occurrence of a natural disaster will generally bring a large loss for these countries.

The Centre for Research on the Epidemiology of Disasters (CRED) report (2016) has revealed that seven times more people are killed by natural disasters in developing countries $(920,021$ people) than in developed countries (124,706 deaths). The Asia region is most vulnerable to catastrophic risks, with 69,293 people dying from natural disasters here. Thus, disasters are especially prevalent in the most populous regions of the world (especially Asia) and are most catastrophic in the poorest countries (e.g. Haiti in 2010). Empirical evidence is required to understand the linkages of disasters, their impacts on the poor and their role in creating and sustaining poverty and generating poverty traps, issues that are likely to become even more acute with changes associated with human-induced climate change, itself predicted to become more extreme in poorer countries and hence placing additional barriers to poverty alleviation. Empirical and theoretical research on disasters has evaluated the impacts of natural disasters on a diverse range of social and economic issues: the economic growth impact of disasters in the short and long terms, the fiscal impact of disasters, the impact on international trade and financial flows, the impact on populations through migration and fertility choices, the impact on human capital accumulation, the importance of political economy in shaping disasters' aftermaths, and other related topics. Research on the impact of disaster shocks specifically on the poor represents one branch of this wider 'disaster' literature that has yet to be adequately summarized, and no attempt has been made to reach any general conclusions from the numerous case studies that constitute the bulk of this research stream.

One of the tools we can use to reduce natural disasters' effects is through technology alleviation. This is because technology has long been recognized as playing an important role in reducing loss of life and damage from disasters. However, in developing countries levels of technology are generally not sufficiently advanced to cope with natural disasters, hence their impact may be in the opposite direction. In other words, a rise in technology can actually cause more poverty. This situation might indicate that the technology uses in target countries are focused on manufacturing and agriculture in order to increase productivity (Kassie et al. 2011; Liverpool \& Winter-Nelson 2010; Minten \& Barret 2005) and thus boost their economies. Certainly, if technology expenditure largely focuses on these sectors, the technology required to cope with natural disasters may be neglected. Furthermore, developing countries have limited resources and specialists, and so poverty gaps may be exacerbated when a natural disaster strikes. Education levels in developing countries are also much lower than in developed countries. Education is crucial to train specialists and create general public awareness so that people can take the most appropriate actions during a disaster event. In contrast, a lack of education can lead to heavier-than-expected losses because awareness is insufficient.

This study differs from previous empirical studies by examining the impacts of natural disasters, technological change and education on poverty rates using data from 38 developing countries. Past studies have examined the existence of a causal link between natural disasters and poverty, but remain limited in this regard (see Israel \& Briones 2013; 2014; Rodriques et al. 2009) because they use micro-level data for single countries. Instead, the present study utilizes longitudinal data for 38 countries at a macro level. Thus, empirical evidence from previous studies examine the relationship between natural disasters and poverty still limited and this study can fill this gap in terms of knowledge level and technological change indirectly causes more poverty using panel data approach instead using OLS done by the previous study.

The remainder of this paper is structured as follows: the next section presents the literature review, which is followed by the methodology and data description, while the fourth section provides the empirical results. The final section presents a summary and conclusion.

\section{LITERATURE REVIEW}

A first group of studies is focused on the effects of natural disasters on low-income households (Carter et al. 2007), welfare (Van den Berg 2010) and poverty (Rodriques et al. 2009). A second group of studies reveals the negative effects of natural disasters on household income per capita (Israel \& Briones 2014) and economic growth per capita (Klomp \& Valckx 2014). The third group of studies indicates that technological improvements can reduce poverty in the agricultural sector (for example, Kassie et al. 2011; Liverpool \& Winter-Nelson 2010), while finally a few studies have noted that education level is indirectly reduced to poverty (Gounder \& Xing 2012; Muttarak \& Lutz 2014).

Carter et al. (2007) have found that environmental shocks can have significant impacts on poor households, trapping them in an impoverished position from which they cannot escape. When this happens, a humanitarian problem of disaster relief becomes a long-term development issue. In the fictive world of full and complete markets, poor households might be 
able to draw on loans and insurance contracts to cope with the often disastrous asset and income losses brought about by severe environmental shocks. Drawing on future earnings, households could rebuild lost assets and sustain their level of current consumption without the further depletion of their productive assets and future possibilities.

According to Van den Berg (2010), large parts of the developing world are at substantial risk of being hit by natural hazards such as earthquakes, droughts, floods and hurricanes. People living in these areas have limited capacity to cope with shocks and consequently natural disasters can have persistent effects on welfare. Through destruction or the distressed sales of productive assets, a natural hazard could thus stimulate people with relatively remunerative livelihoods to choose more defensive strategies, enabling them to survive but at a permanently lower welfare level than before. Therefore, they will struggle in poverty traps. In short, when the risk of happened the natural disaster becomes higher and the welfare of communities becomes lower.

Three studies have used data on single countries to identify a strong positive relationship between a natural disaster and poverty. According to Rodriguez-Oreggia et al. (2009), municipalities affected by flooding in Mexico experienced an increase in poverty by between 1.5 and 3.6\%. Rush (2013) has stated that natural disasters can increase the percentage of the population in poverty by $0.8 \%$ and expand the poverty gap by $2.28 \%$, indicating that natural disasters can reduce inequality among the poor and are associated with a lower poverty line in the case of real losses, as the poverty rate will become higher. Israel and Briones $(2014 ; 2013)$ have demonstrated the impact of natural disasters on income and poverty using household level data in the Philippines, noting that natural disaster variables showed a significant negative relationship with household income per capita, and hence highlighting how natural disasters particularly affect households with lower incomes. This direct reduction of income is likely to have a greater impact on households whose incomes are at the level of poverty to become trapped in poverty.

Klomp and Valckx (2014) have argued that during the last two decades, the frequency and severity of natural disasters have risen dramatically. First, natural disasters seem to have a negative effect on growth. In particular, climatic disasters in developing countries have the most severe impacts on economic growth per capita. There has been a growing impact of natural disasters on economic growth in the last four decades due to the increase in the number of large-scale events. On the other hand, natural disasters only have an impact in the short run, as in the long run gross domestic product (GDP) per capita returns to its original growth path. Felbermayr and Gröschl (2014) and Thomas et al. (2013) have demonstrated the potential impact of natural disasters on economic growth over the medium to long term, noting that in countries with financial sector development, natural disasters have a persistent negative effect on economic growth over the medium term.

In terms of technological improvements and poverty, Liverpool and Winter-Nelson (2010) have suggested a positive impact on farmers' well-being by promoting the use of improved technologies and by directly affecting consumption and asset growth. Interventions to enable the poor to use fertilisers more widely could contribute to both their food security and their ability to escape from poverty. Liverpool and Winter-Nelson's study finds that these effects are not uniformly distributed, being strongest for the never-asset poor. Among households who adopted or stopped using the technologies studied, participation in micro-finance programs only increased less poor households' propensity to use technology. Furthermore, new technologies are more consistently associated with consumption and asset growth among the never-asset poor and the transitory-asset poor than among the always-asset poor. The one exception is fertiliser use, whose impact on consumption and asset growth appears to cut across all poverty classes.

Following by Mendola (2007), the propensity score matching (PSM) estimation method and the adoption of highyielding varieties (HYVs) of rice revealed a positive impact on farm household well-being. Allowing for interactions between agricultural technology and other determinants of income, this method leads us to quantify the positive impact of technology adoption on resource-poor farmers in terms of the rise in income and poverty reduction. Kassie et al. (2011) suggest using PSM methods that adopting improved groundnut varieties (technology) significantly increases crop income and reduces poverty. The positive and significant impact on crop income is consistent with the perceived role of new agricultural technologies in reducing rural poverty through increased farm household income rates. This study supports broader investment in agriculture research to address vital development challenges. Nevertheless, reaching the poor using better technologies requires policy support to improve extension efforts, access to seeds and market outlets that stimulate adoption.

Maintain and Barrett (2005) suggests that increases in agricultural yields are strongly associated with gains for each of these subpopulations of the poor. Greater rice productivity outstrips local market price declines and therefore benefits net sellers. However, higher rice yields primarily appear to help the two other subpopulations, that is, the poor in rural areas, by driving down consumer food prices and boosting unskilled workers' real wages. Thus, the poverty rates will be reduced. Basher (2013) has stated that the application of science and technology can substantially reduce losses of lives and poverty. For example, in Bangladesh a national flood warning system is helping millions of villagers to defend themselves against regular flooding and to preserve household assets. These studies have indicated that approximately US\$40 is saved for every dollar invested in the installation of a warning system, a saving of US\$400-500 per affected household.

The final important issue pertains to education and the poverty line. Muttarak and Lutz (2014) have tested the hypothesis that education is key in reducing vulnerability to climate change because it can directly influence risk perception, skill and knowledge and indirectly reduce poverty and improve health. In particular, it is interesting to note 
that education almost always turns out to be more important than income in reducing disaster vulnerability. The protective effects of education during the disaster phase can have a positive externality in reducing and enhancing adaptive capacity. Gounder and Xing (2012) have claimed that monetary results indicate that all income quartile households' benefit from the additional skills obtained through formal education. However, although those in the lowest income quartile benefits the most from formal education, this cannot sustainably prevent people with only primary education from falling into poverty. The results for non-monetary models show that education has a positive and significant influence on people's tendency to engage in health prevention activities and to acquire good housing facilities. Jung and Thorbecke (2003) have suggested that an increase in public expenditure on education can contribute to economic growth and poverty alleviation. Their results also imply that the poverty and growth effects of education expenditure will differ across countries. Nevertheless, an important implication of the experimental results is that to maximize their beneficial impact, increases in education expenditure should be supported by appropriate policy measures.

In addition, improving education in Ghana has an important role to play in increasing welfare and reducing poverty in that country, but at the same time patterns of educational and economic disadvantage are found to overlap and potentially prove mutually reinforcing. Part of the benefit of education as an investment good is clearly 'positional', and it is perhaps rather more difficult to implement policies to address access to the levels of education associated with such benefits as lucrative formal sector employment than to implement policies to expand basic-level access, which do not substantially alter patterns of either educational or economic position (Rolleston 2011).

From previous reviews, it can be concluded that natural disasters may affect the economic growth of the country involved and have a negative impact on the income level of its population, thereby placing additional barriers to poverty alleviation. As such, the development of human capital quality through education has the potential to reduce poverty rates through formal education or public expenditure on education. Nevertheless, a review of past empirical works found that only three studies have examined this relationship (see Israel \& Briones 2013; 2014; Rodriques et al. 2009), all of which via micro-level data for single countries and using different measurements of variables for educational and technological change. Therefore, empirical evidence from previous studies regarding any causal link between natural disasters and poverty remains limited, with the present investigation aiming to fill this gap. Indeed, using the panel data method of estimation, covering 38 countries affected by natural disasters, it uses much more data than previous studies.

\section{METHODOLOGY AND DATA DESCRIPTION}

This study uses secondary data source were obtained from two major reports. Firstly, the natural disaster index is obtained from EM-DAT database which included five countries' data from the year 1984 to 2013. The data included the total damage of natural disaster in economics, total affected people and total death after the disaster. Secondly, the poverty rates, the education data, GDP, technology, value are sourced from World data bank begin from 1984 to 2013. After checking and screening for missing variables, unbalance panel data of 359 observations of 38 countries remained for estimation. The poverty is showing by the poverty gaps, education is expressed as the school enrollment in secondary school and technology is expressed as the expenditure in research and development. GDP value is the current GDP or real GDP of each country. In detail, the measurements of variable and expected sign of the parameter are shows in Table 1.

TABLE 1. Measurement of variables and expected sign of the parameter

\begin{tabular}{|c|c|c|c|}
\hline Variable & Definition & Source of Data & Expected Sign of Parameter \\
\hline Poverty Rate & $\begin{array}{l}\text { Poverty rates are the people who living } \\
\text { in the situation below } \$ 1.25 \text { a day } \\
\text { (WHO, 2010). Thus, poverty gap at } \\
\$ 1.25 \text { a day (PPP) (\%) is being used to } \\
\text { calculate the poverty rates of each } \\
\text { country. The poverty gaps are mean } \\
\text { shortfall from the poverty line (counting } \\
\text { the non-poor as having zero shortfall), } \\
\text { expressed as a percentage of the poverty } \\
\text { line. }\end{array}$ & World Bank report (2016) & \\
\hline Real GDP & $\begin{array}{l}\text { Dividing current GDP with the consumer } \\
\text { price index (CPI) }\end{array}$ & World Bank report (2016) & - \\
\hline Education & $\begin{array}{l}\text { Total percentage of the secondary } \\
\text { schools with the proportional of the } \\
\text { population }\end{array}$ & World Bank report (2016) & - \\
\hline Technology & $\begin{array}{l}\text { Total expenditure given for } R \& D \\
\text { divides by the total GDP of the particular } \\
\text { years and calculates as a percentage }\end{array}$ & World Bank report (2016) & + \\
\hline Natural Disaster & $\begin{array}{l}\text { Total number of affected people of } \\
\text { natural disaster }\end{array}$ & EM-DAT database & + \\
\hline Natural Disaster1 & Total damage of natural disaster & EM-DAT database & + \\
\hline
\end{tabular}

Notes: EM-DAT refer Emergency events database for disasters 


\section{MODEL SPECIFICATION}

In order to determine the relationship among poverty rates, RGDP, education, technology and natural disaster impact, we employ a panel data model. This model specification adopted from a previous study was done by the Israel and Briones (2013; 2014). Model specification can be formed as equation (1) examined below:

$$
\log \mathrm{POV}_{i t}=\beta_{0}+\beta_{l} \log \mathrm{RGDP}_{i t}+\beta_{2} \log \mathrm{EDU}_{i t}+\beta_{3} \log \mathrm{TECH}_{i t}+\beta_{4} \log (\mathrm{ND})_{i t}+\mu_{\mathrm{i}}+\varepsilon_{i t}
$$

Where $\mathrm{i}$ and $\mathrm{t}$ denote the number of country $\mathrm{i}=1, \ldots . \mathrm{N}$ and time $\mathrm{t}=1, \ldots, \mathrm{T}$ respectively. The variable $\log \mathrm{POV}$ represents the logarithm of the poverty rate, $\log$ RGDP represents the logarithm of the real GDP, $\log$ EDU represents the logarithm of enrollment rates in secondary school, $\log \mathrm{TECH}_{\mathrm{it}}$ represents the logarithm of expenditure for research and development, and $\log (\mathrm{ND})$ is the effect of a natural disaster in which included the logarithm of total affected people and the logarithm of the value of total damage. In addition to the equation (1), $\beta_{0}$ is a constant, $\mu_{\mathrm{i}}$ is a the individual specific random error component of country $i$ and $\varepsilon_{i t}$ is the remainder error term or idiosyncratic random term (Bhaumik 2015) and fulfill assumption $\mathrm{N} \sim\left(0, \sigma^{2}\right)$. These assumptions imply that individual error components are not correlated with each other and also not correlated across countries and time series.

\section{ESTIMATION METHOD SELECTION}

The pooled regression method, random effect and fixed effect are chosen as the methods of estimation. The most appropriate methods will be chosen between the two methods by using a different statistics test approach. First approach using Breusch-Pagan, Lagrangian Multiplier (BPLM) is used to test pooled model and random effect model (Breusch \& Pagan 1980) and second formulate Hausman statistic test is used to test the random effect model and fixed effect model (Hausman 1978). First approach (BPLM) testing is to select appropriate model estimation in between pooled model and random effect model. Hypothesis testing is Ho: $\mu_{\mathrm{i}}=0$ (Pooled Model) verse $\mathrm{H}_{1}: \mu_{\mathrm{i}} \neq 0$ (Random Effect Model). When the calculated value in the (BPLM) test (refer to equation 2) exceeds the tabulated chi-squared value, this suggest that the random effect model is more appropriate than pooled model. Then the BPLM statistic is as below:

$$
B P L M=\frac{n T}{2(T-1)}\left[\frac{\sum_{i=1}^{n}\left[\sum_{t=1}^{T} \hat{\varepsilon}_{i t}\right]^{2}}{\sum_{i=1}^{n} \sum_{t=1}^{T} \hat{\varepsilon}_{i t}{ }^{2}}-\left.1\right|^{2} \sim \chi_{(d f)}^{2}\right.
$$

Where $\mathrm{n}$ is the number of cross section; $\mathrm{T}$ is number of time and error term from OLS estimation.

The second approach is the selection of the model between fixed effect model (individual differences use dummy variables) and random effect model (individual differences capture by random error term). Hypothesis testing is Ho: $\hat{\beta}_{F E M}$ and $\hat{\beta}_{R E M}$ are consistent, but $\hat{\beta}_{F E M}$ is inefficient (Random Effect Model) verse $\mathrm{H}_{1}$ : $\hat{\beta}_{F E M}$ is consistent and efficient but $\hat{\beta}_{R E M}$ is inconsistent (Fixed effect model). When the Hausman statistic is larger or equivalently the p-value of the test is fewer than $5 \%$ (prob $<0.05$ ), this indicates that the random effects model is not appropriate and that the fixed effects specification is to be preferred. Therefore, two estimators for $\beta_{\text {: }} \beta_{\mathrm{FEM}}$ and $\beta_{\mathrm{REM}}$ were compared. Under the null hypothesis, this statistic has asymptotically the chi-squared distribution with the number of degrees of freedom equal to the rank of matrix $\operatorname{Var}\left(\hat{\beta}_{F E M}\right)-\operatorname{Var}\left(\hat{\beta}_{R E M}\right)$. If the null hypothesis was rejected, it means that $\hat{\beta}_{R E M}$ is inconsistent (Hausman 1978), so fixed effect model was selected. Subsequently the $\mathrm{Wu}-$ Hausman statistic can be expressed as an equation (3):

$$
H=\frac{\left(\widehat{\beta}_{F E M}-\widehat{\beta}_{R E M}\right)^{2}}{\operatorname{Var}\left(\widehat{\beta}_{F E M}\right)-\operatorname{Var}\left(\widehat{\beta}_{R E M}\right)} \sim \chi_{(d f)}^{2}
$$

The main differences between FEM model and REM model are about their assumptions about $\mathrm{u}_{\mathrm{i}}$, and $\varepsilon_{i t}$ and also the estimation method on both models. An important assumption of the FEM model is that those time-invariant are unique, so that the country error term and the constant should not be correlated with others where $\mathrm{E}\left(\mathrm{u}_{\left.\mathrm{i}, \varepsilon_{i t}\right)}\right)$ equal to zero. That mean, the slope of the coefficient of the regression model does not vary across countries or over times. The Least-Square Dummy Variables (LSDV) technique is an appropriate method to estimate the FEM. However, if the error terms are correlated $\mathrm{E}\left(\mathrm{u}_{\mathrm{i}} \varepsilon_{i t}\right)$ is not equal to zero, then FEM is not suitable since inferences may not be inefficient. Thus, REM is an appropriate approach to be used. This is because the composite error term consists two component errors, in which, the country component $\left(\mu_{\mathrm{i}}\right)$ and combine times series and country error component $\left(\varepsilon_{i t}\right)$ as in equation (1). Therefore, the Generalized Least Squares (GLS) estimator is an appropriate technique to be used in handling the correlation problem among the composite error terms. 


\section{EMPIRICAL RESULTS}

To identify which model is most suitable among pooling, random effect and fixed effect regression, two statistical tests were performed. First, the BPLM test is used. The chi-squared statistics reported in Tables 2 (638.29) and Table 3 (632.40) are significant at the $1 \%$ significance level, indicated that the random effects model is more appropriate than the pooled model. Second, the Hausman specification test is used to compare the fixed effect model and random effect models. The result of Hausman tests are reported in Tables 2 (8.02) and Table 3 (8.66) showed that the null hypothesis was not rejected at the $1 \%$ significance level, which indicate that the random effects model was more accurate in the estimation of the poverty equation.

Table 2 shows the effects of total affected people in the natural disaster on poverty rate using the random effect model. As can be seen, real GDP exhibits a negative relationship with poverty, implying that the increase in real GDP will lead to a reduction in poverty of $67 \%$ on average, while other variables remain unchanged. This is because when the GDP of the country increases, people have greater job opportunities and so can move out from the poverty gaps. A high GDP is achieved by good economic performance.

The estimated results demonstrate that the relationship between education and poverty is negative and statistically significant at $1 \%$. This means that raising the education level by $1 \%$ will reduce poverty by $1.9 \%$ on average, assuming that other variables are unchanged. The reasoning is that boosting the number of knowledgeable people in a country will increase the country's productivity, the economy will become more efficient and the output will increase. Therefore, poverty gaps will be reduced.

The technology level has a positive relationship with poverty. An increase in technology will stimulate a rise in poverty rates. The reason of the result might cause by the factor of the capitals. When technology levels are advanced, factories will use machines to replace workers. Therefore, the unemployment rate will increase, stimulating an increase in poverty rates. From the aspect of total affected people in a natural disaster, the link with poverty is positive. This shows that when the people suffer from the natural disaster is increasing, this incidence will increase the poverty rates. This is relevant when the natural disaster causes a large amount of people affected lead them to lose their home, lost their property as well as the income. In short, an increase in one percent of the total affected people by natural disaster, 3\% of people will trap in the poverty gaps.

TABLE 2. Total affected of natural disasters on poverty

\begin{tabular}{|c|c|c|c|}
\hline Variable & Pooled Model & Random Effect Model & Fixed effect Model \\
\hline $\operatorname{logRGDP}$ & $\begin{array}{c}-0.182 * * * \\
(-3.65)\end{array}$ & $\begin{array}{c}-0.373 * * * \\
(-4.43)\end{array}$ & $\begin{array}{c}-0.723 * * * \\
(-6.02)\end{array}$ \\
\hline Logedu & $\begin{array}{l}-2.552 * * * \\
(-11.47)\end{array}$ & $\begin{array}{c}-1.797 * * * \\
(-4.45)\end{array}$ & $\begin{array}{c}--0.926 * * \\
(-1.64)\end{array}$ \\
\hline $\log$ Tech & $\begin{array}{c}-0.482 * * * \\
(-4.63)\end{array}$ & $\begin{array}{c}0.129^{*} \\
(1.76)\end{array}$ & $\begin{array}{l}0.526 * * * \\
(2.53)\end{array}$ \\
\hline $\log \mathrm{NDTA}_{\mathrm{T}}$ & $\begin{array}{c}0.128 * * * \\
(6.72)\end{array}$ & $\begin{array}{l}0.045 * * \\
(3.44)\end{array}$ & $\begin{array}{c}0.031 * * * \\
(2.36)\end{array}$ \\
\hline Constant & $\begin{array}{c}14.574 * * * \\
(8.97)\end{array}$ & $\begin{array}{l}17.003^{* * * *} \\
(6.62)\end{array}$ & $\begin{array}{l}21.192 * * * \\
(7.7 .02)\end{array}$ \\
\hline $\mathrm{R}^{2}$ & 0.436 & 0.273 & 0.037 \\
\hline Adjusted $\mathrm{R}^{2}$ & 0.413 & 0.262 & 0.018 \\
\hline Times $(\mathrm{T})$ & 39 & 39 & 39 \\
\hline Country $(\mathrm{N})$ & 38 & 38 & 38 \\
\hline LM Test & & $000)$ & \\
\hline Hausman Test & & & \\
\hline
\end{tabular}

Notes: Estimated obtained from 359 observations using pooled, random and fixed effect with the standard errors, *,**,***, indicate statistical significance at $10 \%, 5 \%$, and $1 \%$ respectively. Values inside the bracket represent t-statistic value of the test. Symbol subscripts TA refer to variable Total affected by natural disaster.

Table 3, denotes that the total damage of natural disaster and the effects towards the poverty also based on random effect model. In this model, three out of the four variables are significant at $5 \%$ except for technology change variables. Coefficient of $\log$ RGDP indicated a negative relationship with the poverty rate. For instance, the raise of the real GDP causes the poverty gaps to decrease on average by $0.46 \%$ by assuming that other variables are constant. The situation shows that when the development of economics in the country arising will successful declination in the poverty.

Seconds variables are education level. Results obtained in Table 3 also indicate that the relationship between education and poverty are negative and also statistically significant at $1 \%$. That means raising the education level by $1 \%$ will be decreased poverty on average by $1.9 \%$ with assumption other variable unchanged. This finding indicates that the upsurge of education levels will reduce the poverty gaps. The ratiocination is because of boosting in the knowledgeable people in the appropriate country will increase the productivity of the country. The economy will become more efficient and the output will increase. Hence, the poverty gaps will be closer. 
Nonetheless, technology has a positive relationship and significant at $10 \%$ in influencing the poverty gaps. Advances in technology will increase the use of machines in manufacturing sectors, labour demand will decline and poverty gaps will expand. The final variable is total persons affected by natural disasters, which stated that an increase of total affected persons has also exacerbated the poverty gaps. The country will suffer from the loss of workforce productivity due to deaths related to natural disasters. Some families (especially the poor) will lose their main financial income when the central actor generating incomes are killed. As a result, the poverty gap becomes wider.

TABLE 3. Total damage of natural disasters on poverty

\begin{tabular}{|c|c|c|c|}
\hline Variable & Pooled Model & Random Effect Model & Fixed effect Model \\
\hline $\operatorname{logRGDP}$ & $\begin{array}{c}-0.194 * * * \\
(-3.34)\end{array}$ & $\begin{array}{c}-0.458 * * * \\
(-5.18)\end{array}$ & $\begin{array}{c}-0.723 * * * \\
(-6.49)\end{array}$ \\
\hline $\operatorname{lnEdu}$ & $\begin{array}{c}-2.581 * * * \\
(-11.06)\end{array}$ & $\begin{array}{c}-1.88 * * * \\
(-4.44)\end{array}$ & $\begin{array}{c}-1.107 * * \\
(-1.97)\end{array}$ \\
\hline lntech & $\begin{array}{c}-0.422 * * * \\
(-3.80)\end{array}$ & $\begin{array}{l}0.250^{*} \\
(1.72)\end{array}$ & $\begin{array}{l}0.578^{* * *} \\
(2.76)\end{array}$ \\
\hline $\operatorname{lnND}{ }_{\mathrm{TD}}$ & $\begin{array}{l}0.782 * * * \\
(4.33)\end{array}$ & $\begin{array}{c}0.025^{* * *} \\
(2.20)\end{array}$ & $\begin{array}{l}0.017 \\
(1.48)\end{array}$ \\
\hline Constant & $\begin{array}{l}14.28 * * * \\
(8.43)\end{array}$ & $\begin{array}{l}19.384^{* * * *} \\
(7.41)\end{array}$ & $\begin{array}{l}22.981 * * * \\
(7.83)\end{array}$ \\
\hline $\mathrm{R}^{2}$ & 0.396 & 0.273 & 0.037 \\
\hline Adjusted $\mathrm{R}^{2}$ & 0.376 & 0.256 & 0.017 \\
\hline Times $(\mathrm{T})$ & 39 & 39 & 39 \\
\hline Country $(\mathrm{N})$ & 38 & 38 & 38 \\
\hline LM Test & \multirow{2}{*}{\multicolumn{3}{|c|}{$632.40 * * *(0.000)$}} \\
\hline Hausman Test & & & \\
\hline
\end{tabular}

Notes: Estimated obtained from 359 observations using pooled, random and fixed effect with the standard errors, $*, * *, * * *$, indicate statistical significance at $10 \%, 5 \%$, and $1 \%$ respectively. Values inside the bracket represent $\mathrm{t}$-statistic value of the test. Symbol subscripts TD refer to variable Total damage of natural disaster.

\section{SUMMARY AND POLICY RECOMMENDATION}

The estimation results show that the natural disasters variable proxies by total affected people and total damage have negative relationships with poverty. This means that an increase in the total number of affected people and the total damage from natural disasters by $1 \%$ will lead to a decline in poverty by $0.05 \%$ (Table 2) and $0.03 \%$ (Table 3 ) respectively. Thus, the new findings revealed that natural disasters may bring a negative effect to countries, creating substantial damage and instigating a rise in poverty gaps. In addition, developing countries may lack the resources to handle natural disasters efficiently, and so will suffer significant losses.

The results also indicate that the relationship between education and poverty are negative and statistically significant at $1 \%$. This is because education levels in developing countries are much lower than developed countries, and so they lack the specialists necessary to mitigate damage from a natural disaster. Education can also increase public awareness, necessary to help them take the right actions when a natural disaster occurs. In addition, the technology variable has a significant at $5 \%$ and positive relationship with poverty. This may demonstrate that technology in the target countries is mainly focused on manufacturing sector in order to increase productivity and economic development, while neglecting investment on technologies for disaster mitigation. Coupled with the general lack of specialists and resources, poverty gaps will be exacerbated by natural disasters.

There are three suggestions for policy makers in minimizing the impacts of natural disasters. First, developed countries should help developing or low-income countries by providing an assistance in technology development (especially where it can minimize damage), and also can share designs of shelters or buildings that are more resistant to damage. In addition, the developed countries also play a pivotal role after the incidence of disaster by sending volunteers, food, water and financial support, thereby reducing the potential for poverty gaps to expand. Second, local government and international association also play an important role in minimizing damage to the affected people. For instance, local government can encourage research and development in technology, and government campaigns can be used to increase public awareness. In addition, international associations can create new policies with standard rules of measurement to facilitate natural disaster awareness and thus minimize natural disasters' impacts. Finally, improvements in education can reduce the poverty gap around the world. Knowledgeable people will contribute their wisdom to vulnerable countries in many aspects. Education can lead to new innovations, and people will become more aware. Education also provides the basis for a higher level of technology. With technology, specialists in the natural disaster field can be nurtured. Thus, damage due to natural disasters can be reduced and poverty gaps will be closed. 


\section{REFERENCES}

Basher, R. 2013. Science and technology for disaster risk reduction: A review of application and coordination needs. UN International Strategy for Disaster Reduction (UNISDR). Retrieved from https://www.preventionweb.net/posthfa/documents/Science-and-Technology-for-Disaster-Risk-Reduction.pdf.

Berloffa, G. \& Modena, F. 2013. Income shocks, coping strategies, and consumption smoothing: An application to Indonesian Data. Journal of Asian Economics 24: 158-171.

Breusch, P. \& Pagan, A. 1980. The LM test and its applications to model specification in econometrics. Review of Economics Studies 47: 239-254.

Carter, M. R., Little, P. D., Mogues, T. \& Negatu, W. 2007. Poverty traps and natural disasters in ethiopia and honduras. World Development 35(5): 835-856.

Centre Research on Epidemiology of Disasters (CRED). 2016. Poverty and deaths: disaster mortability $1996-2015$. Retrived 4 August 2018 from https://www.emdat.be/publication.

Felbermayr, G. \& Gröschl, J. 2014. Naturally Negative: The Growth effects of natural disasters. Journal of Development Economics 111: 92-106.

Gounder, R., \& Xing, Z. 2012. Impact of education and health on poverty reduction: monetary and non-monetary evidence from Fiji. Economic Modelling 29(3): 787-794.

Hallegatte, S. \& Prsyluski, V. 2010. The economics of natural disasters concepts and methods. Policy Research Warking Paper 5507. https://www.researchgate.net/publication/228203903_The_Economics_of_Natural_Disasters_Concepts_ and_Methods. ( accessed 24 November 2017)

Hausman, J.A. 1978. Specification tests in econometrics. Econometrica 46:1251-1271

Israel, D.C. \& Briones, R.R. 2013. The impact of natural disasters on income and poverty: framework and some evidence from Philippina households. Community Base Monitoring System International Network. XI: 1- 7

Israel, D.C. \& Briones, M.R. 2014. Disasters, Poverty and Coping Strategies: The Framework and Empirical Evidence from Micro/Household Data-Philippine Case. PIDS Discussion Paper No. 2014-06.

Jakobsen, K. 2012. In the eye of the storm: The welfare impacts of a hurricane. World Development 40:2578-2589.

Jung, H. S., \& Thorbecke, E. 2003. The impact of public education expenditure on human capital, growth, and poverty in Tanzania and Zambia: A General Equilibrium Approach. Journal of Policy Modeling 25(8): 701-725.

Kassie, M., Shiferaw, B. \& Muricho, G. 2011. Agricultural technology, crop income, and poverty alleviation in Uganda. World Development 39(10): 1784-1795.

Klomp, J. \& Valckx, K. 2014. Natural disasters and economic growth: A meta-analysis. Global Environmental Change 26: 183-195.

Liverpool, L. S. O., \& Winter-Nelson, A. 2010. Poverty status and the impact of formal credit on technology use and wellbeing among Ethiopian smallholders. World Development, 38(4): 541-554.

Mechler, R. 2009. Disasters and economic welfare: Can national savings help explain post disaster changes in consumption? (Policy Research Working Paper No. 4988). Retrieved 24 Disember 2017 from World Bank website.

Mendola, M. 2007. Agricultural technology adoption and poverty reduction: A propensity-score matching analysis for rural Bangladesh. Food Policy 32(3): 372-393.

Minten, B. \& Barrett, C. B. 2005. Agricultural technology, productivity, poverty and food security in Madagascar. Retrieved 24 November 2017 from https://dx.doi.org/10.2139/ssrn.716142

Muttarak, R. \& Lutz, W. 2014. Is education a key to reducing vulnerability to natural disasters and hence unavoidable climate changes? Journal of Ecology and Society 19(1): 42.

Qianwen, G. \& Junbiao, Z. 2007. Relations between agricultural, natural disasters and rural poverty based on analysis of panel data in Anhui Province, China. China Population, Resources and Environment 17(4): 92-95.

Rolleston, C. 2011. Educational access and poverty reduction: The case of Ghana 1991-2006. International Journal of Educational Development 31(4): 338-349.

Rush, V.J. 2013. The Impact of Natural Disasters on Poverty in Indonesia.https://pdfs.semanticscholar.org/8888/ebd41d4d 478caaebe5b762ede0e67eda9174.pdf (accessed 4 August 2018).

Bhaumik, S.K. 2015. Principles of Econometrics. A Modern Approach using Eviews. Oxford University Press: New Delhi

Thomas K.J., McDermott, F.B. \& Richard S.J. 2013. Disasters and development: natural disasters, credit constraints and economic growth. Oxford Economic Paper 66(3): 750-773.

Van den Berg, M. 2010. Household income strategies and natural disasters: Dynamic livelihoods in rural Nicaragua. Ecological Economics 69(3): 592-602.

Rodriguez-Oreggia E., de la Fuente A., de la Torre R., Moreno H. \& Rodriguez C. 2009. The impact of natural disasters on human development and poverty at the municipal level in Mexico. Manuscript

World Bank. 2016. World Development Indicators. http://data.worldbank.org /datacatalog/world-development-indicators. (accessed 6 June 2018).

WHO. 2010. World Health Statistics 2010. 


\section{Jaharudin Padli}

Faculty Business, Economics and Social Development

Universiti Malaysia Terengganu

21030 Kuala Terengganu, Terengganu

E-mail: nizamahmat@umt.edu.my

Nizam Ahmat*

Faculty Business, Economics and Social Development Universiti Malaysia Terengganu

21030 Kuala Terengganu, Terengganu

E-mail: nizamahmat@umt.edu.my

Mohd Nasir Nawawi

Faculty Business, Economics and Social Development Universiti Malaysia Terengganu

21030 Kuala Terengganu, Terengganu

E-mail : nasir@umt.edu.my

\footnotetext{
* Corresponding author
} 